\title{
Vocabulary Mastery with Storytelling Methods and Conventionality Strategies and References to Students in The A1 TK Rahma Ciracas
}

\author{
Endang Sulistijani ${ }^{*}$, \\ Universitas Indraprasta PGRI \\ *) Jalan Rambutan, Gg. Batas Barat II No. 24 RT 05/10, Kel. Baru Jakarta Timur, Indonesia; \\ e-mail: endangsmg711@gmail.com
}

\begin{abstract}
Teaching languages in early childhood (3-5 years of age) requires a fun method. In early childhood it is commonly referred to as The Golden age. Stories need to be given to children considering the many benefits that can be obtained from a story. Besides giving pleasure and presenting various experiences and insights for children, stories are thought to be able to improve children's language skills. This study aims to describe the process of mastering the vocabulary of children through the method of telling stories with conventionality and reference strategies for A1 grade students at TK Rahma Ciracas. The research method used is descriptive qualitative with observation, interviews, and recording results. With conventional strategies and references, mastery of vocabulary in children is more focused and directed, so mistakes in determining their meaning can be avoided. In addition, the method of telling stories with this strategy is very effective for language teaching in early childhood.
\end{abstract}

Keywords: vocabulary, early childhood, storytelling method, conventionality strategy, reference strategy.

Article History: Received: 23/05/2019; Revised: 20/06/2019; Accepted: 20/07/2019; Published: 31/07/2019. How to Cite (MLA $7^{\text {th }}$ ): Sulistijani, Endang. "Vocabulary Mastery with Storytelling Methods and Conventionality Strategies and References to Students in the al TK Rahma Ciracas." Hortatori Jurnal Pendidikan Bahasa dan Sastra Indonesia 3.01 (2019): 52-63. Print/Online. Copyrights Holder: Sulistijani, Endang. First Publication: Hortatori Jurnal Pendidikan Bahasa dan Sastra Indonesia (2019).

This work is licensed under a Creative Commons Attribution-ShareAlike 4.0 International License.

\section{Pendahuluan}

Dunia pendidikan secara terus-menerus mengalami proses perubahan dan perkembangan. Perkembangan ini berawal dari tidak ada menjadi ada, dari yang sudah ada menjadi lebih baik, dari yang sudah baik menjadi lebih baik lagi, dan seterusnya. Proses perubahan yang terjadi di dunia pendidikan kita saat ini secara tidak langsung menyebabkan terjadinya pergeseran dalam masyarakat.

Salah satu tuntutan masyarakat terhadap dunia pendidikan kita adalah mampu menciptakan manusia yang memiliki kemampuan dalam melakukan kerja sama dengan orang lain. Taman Kanakkanak sebagai lembaga pendidikan formal tingkat awal sebelum Sekolah Dasar juga harus mampu menanamkan sikap kerja sama dengan orang lain. Hal ini dilakukan dengan menjalankan kreativitas dalam proses pembelajaran di sekolah. Namun, hal ini pun juga tidak dapat terlepas dari prinsip "Belajar sambil Bermain, Bermain seraya Belajar" dalam proses pembelajaran yang dilakukan. Selain itu, perlu juga diperhatikan bahwa batasan pembelajaran pada lembaga seperti PAUD dan TK adalah tidak menargetkan pada suatu hasil, tetapi pada prosesnya. Jika prosesnya benar dan baik, hasilnya juga akan baik.

Di dalam Kurikulum Berbasis Kompetensi TK 2004 terdapat dua formula besar yang harus dikembangkan yaitu pembentukan perilaku dan pembentukan kemampuan dasar. Pembentukan perilaku dijabarkan ke dalam empat poin, diantaranya: moral dan nilai-nilai agama; sosial; emosional; dan kemandirian. Adapun kemampuan dasar juga dijabarkan ke dalam empat poin juga, yaitu berbahasa; 
kognitif; fisik/motorik; dan seni. Oleh karena itu, guru PAUD/TK harus dapat memahami kemampuan unik anak didiknya.

Menurut Moeslichatoen (2004), kemampuan-kemampuan yang harus dimiliki oleh anak seusia TK adalah Berkembang menjadi pribadi yang mandiri; Belajar memberi, berbagi, dan memperoleh kasih sayang; Belajar bergaul dengan anak lain; Mengembangkan pengendalian diri; Belajar bermacam-macam peran orang dalam masyarakat; Belajar untuk mengenal tubuh masing-masing; Belajar menguasai keterampilan motorik halus dan kasar; Belajar mengenai lingkungan fisik dan mengendalikannya; Belajar menguasai kata-kata baru untuk memahami orang/anak lain; dan Mengembangkan perasaan positif dalam berhubungan dengan lingkungan. Agar kemampuan-kemampuan dasar tersebut dapat tertanam pada anak PAUD/TK secara baik, perlu adanya metode pembelajaran yang direncanakan oleh guru secara tepat. Metode atau cara yang digunakan dalam pembelajaran di PAUD/TK antara lain metode bermain, metode karyawisata, metode bercakap-cakap, metode demonstrasi, metode proyek/penugasan, metode bercerita, atau metode pemberian tugas.

Pemilihan metode pembelajaran harus disesuaikan dengan kemampuan dasar yang harus dimiliki oleh anak PAUD/TK. Misalnya, kemampuan belajar menguasai kata-kata baru akan lebih tepat menggunakan metode bercerita dibandingkan dengan menggunakan metode pemberian tugas bagi anak. Demikian juga misalnya metode pemberian tugas bagi anak PAUD/TK akan lebih mengena bila digunakan untuk menanamkan kemampuan belajar menguasai keterampilan motorik halus dan kasar, seperti menggunting, menempel, atau melipat.

Berdasarkan deskripsi di atas, peneliti melakukan pengamatan terhadap permasalahan yang terjadi di PAUD/TK Rahma di Ciracas Jakarta Timur, bahwa kemampuan menguasai kata-kata baru (kosa kata dalam bahasa Indonesia) sangat kurang. Hal ini dapat disebabkan oleh beberapa faktor antara lain:

a. Faktor sosial yaitu kurangnya aktivitas bermain antarsiswa yang disebabkan juga fasilitas dan tempat bermain yang kurang sehingga anak kurang berinteraksi.

b. Faktor ekonomi yaitu sebagian besar siswa yang belajar di PAUD/TK Rahma dari keluarga yang kurang mampu.

c. Faktor latar belakang pendidikan keluarga.

d. Metode yang digunakan dalam pembelajaran kurang tepat sehingga anak mudah lupa dan bosan.

Dari gambaran kondisi tersebut, peneliti akan mencoba menerapkan penggunaan metode bercerita dalam meningkatkan kemampuan penguasaan kosa kata baru bahasa Indonesia pada peserta didik di PAUD Rahma di Ciracas Jakarta Timur yang berjumlah 20 anak. Metode ini merupakan salah satu metode yang tidak hanya mampu mengajak siswa untuk berhubungan yang baik dengan temannya, tetapi juga dapat menggali kemampuan berkomunikasi yang dimiliki anak, terutama dalam hal peningkatan penguasaan kosa kata bahasa Indonesia.

Cerita merupakan suatu bentuk karya seni yang tidak hanya memberikan hiburan kepada masyarakat pembacanya, melainkan juga manfaat. Pada anak usia dini yang biasa disebut dengan The Golden age, cerita perlu diberikan kepada anak-anak mengingat banyaknya manfaat yang bisa diperoleh dari cerita. Cerita mampu memberikan nilai intrinsik dan ekstrinsik bagi anak (Tarigan, 1997:67). Selain memberikan kesenangan dan menyajikan berbagai pengalaman dan wawasan bagi anak, cerita ditengarai mampu meningkatkan kemampuan berbahasa anak. Kemampuan berbahasa anak ini perlu diasah agar anak-anak mampu berkomunikasi dan mampu mengekspresikan pikiran maupun perasaan mereka dengan baik.

PAUD/TK Rahma merupakan salah satu sekolah Taman Kanak-kanak rintisan yang ada di Ciracas, Jakarta Timur. TK ini memiliki lima kelas, yakni A1, A2, B1, dan B2. Kelas A1 diperuntukkan bagi anakanak yang berusia antara $3-4$ tahun. Kelas A2 diperuntukkan bagi anak-anak usia $4-5$ tahun, sedangkan kelas B1 dan B2 diperuntukkan bagi anak-anak usia 5-6, anak-anak yang telah siap untuk masuk bangku Sekolah Dasar. Setiap kelas diisi maksimal $15-20$ anak dan diasuh oleh dua orang guru.

Alasan PAUD/TK Rahma sebagai tempat penelitian karena TK ini memerlukan upaya untuk meningkatkan kualitas pengajaran terutama di bidang bahasa. Anak-anak di TK tersebut rata-rata berasal dari keluarga menengah ke bawah dan multikultur. Berdasarkan observasi peneliti, masih banyak peserta didik di kelas A1 (usia 3 - 4 tahun) yang kemampuan bahasanya rendah terutama penguasaan kosa kata. Dari Observasi tersebut ternyata metode yang digunakan guru kurang menarik.Oleh karena itu, dalam penelitian ini digunakan metode bercerita tentang topik binatang (sesuai dengan silabus). 
54 Vocabulary Mastery with Storytelling Methods and Conventionality Strategies and References to Students in The Al TK Rahma Ciracas

Masalah yang akan diteliti ini dibatasi hanya pada penguasaan kosakata dengan strategi konvensionalitas dan referensi dalam bercerita pada anak kelas A1 TK Rahma. Kosakata yang dipilih sesuai dengan silabus yang ada yaitu tentang binatang dan merujuk pada kegiatan atau kebiasaan binatang tersebut.

1. Anak Usia Dini

Anak usia dini adalah anak yang berada pada rentan usia 0-6 tahun (Undang-undang Sisdiknas tahun 2003) dan 0-8 tahun menurut para pakar pendidikan anak. Menurut Mansur (2005: 88) anak usia dini adalah kelompok anak yang berada dalam proses pertumbuhan dan perkembangan yang bersifat unik. Mereka memiliki pola pertumbuhan dan perkembangan yang khusus sesuai dengan tingkat pertumbuhan dan perkembangannya.

Pada masa ini merupakan masa emas atau golden age, karena anakmengalami pertumbuhan dan perkembangan yang sangat pesat dan tidak tergantikan pada masa mendatang. Menurut berbagai penelitian di bidang neurologi terbukti bahwa 50\% kecerdasan anak terbentuk dalam kurun waktu 4 tahun pertama. Setelah anak berusia 8 tahun perkembangan otaknya mencapai $80 \%$ dan pada usia 18 tahun mencapai 100\% (Slamet Suyanto, 2005: 6).

Pada masa masa emas atau golden age hampir seluruh potensi anak mengalami masa peka untuk tumbuh dan berkembang secara cepat dan hebat. Perkembangan setiap anak tidak sama karena setiap individu memilikiperkembangan yang berbeda. Makanan yang bergizi dan seimbang sertastimulasi yang intensif sangat dibutuhkan untuk pertumbuhan danperkembangan tersebut. Apabila anak diberikan stimulasi secara intensif dari lingkungannya, maka anak akan mampu menjalani tugas perkembangannya dengan baik. Masa kanak-kanak merupakan masa saat anak belum mampumengembangkan potensi yang ada dalam dirinya. Mereka cenderung senang bermain pada saat yang bersamaan, ingin menang sendiri dan sering mengubah aturan main untuk kepentingan diri sendiri. Dengan demikian, dibutuhkan upaya pendidikan untuk mencapai optimalisasi semua aspek perkembangan, baik perkembangan fisik maupun perkembangan psikis. Potensi anak yang sangat penting untuk dikembangkan. Potensi-potensi tersebut meliputi kognitif, bahasa, sosioemosional, kemampuan fisik dan lain sebagainya.

Sesuai dengan Undang-undang Sisdiknas tahun 2003 pasal 1 ayat 14, upaya pembinaan yang ditujukan bagi anak usia 0-6 tahun tersebut dilakukan melalui Pendidikan anak usia dini (PAUD). Pendidikan anak usia dini dapat dilaksanakan melalui pendidikan formal, nonformal dan informal. Pendidikan anak usia dini jalur formal berbentuk taman kanak-kanak (TK) dan Raudatul Athfal (RA) dan bentuk lain yang sederajat. Pendidikan anak usia dini jalur nonformal berbentuk kelompok bermain (KB), taman penitipan anak (TPA), sedangkan PAUD pada jalur pendidikan informal berbentuk pendidikan keluarga atau pendidikan yang diselenggarakan lingkungan seperti bina keluarga balita dan posyandu yang terintegrasi PAUD atau yang kita kenal dengan satuan PAUD sejenis (SPS).

Maleong menyebutkan bahwa ragam pendidikan untuk anak usia dini jalur non formal terbagi atas tiga kelompok yaitu kelompok taman penitipan anak (TPA) usia 0-6 tahun); kelompok bermain (KB) usia 2-6 tahun; kelompok satuan PADU sejenis (SPS) usia 0-6 tahun (Harun, 2009: 43).

Dari uraian di atas, dapat ditarik kesimpulan bahwa anak usia dini adalah anak yang berada pada rentang usia 0-6 tahun yang sedang mengalami pertumbuhan dan perkembangan yang sangat pesat, sehingga diperlukan stimulasi yang tepat agar dapat tumbuh dan berkembang dengan maksimal. Pemberian stimulasi tersebut harus diberikan melalui lingungan keluarga, PAUD jalur non formal seperti tempat penitipan anak (TPA) atau kelompok bermain (KB) dan PAUD jalur formal seperti TK dan RA.

2. Karakteristik Anak Usia Dini

Anak usia dini memiliki karakteristik yang khas, baik secara fisik, sosial, moral dan sebagainya. Menurut Siti Aisyah,dkk (2010: 1.4-1.9) karakteristik anak usia dini antara lain; a) memiliki rasa ingin tahu yang besar, b) merupakan pribadi yang unik, c) suka berfantasi dan berimajinasi, d) masa paling potensial untuk belajar, e) menunjukkan sikap egosentris, f) memiliki rentang daya konsentrasi yang pendek, g) sebagai bagian dari makhluk sosial, penjelasannya adalah sebagai berikut.

Usia dini merupakan masa emas, masa ketika anak mengalamipertumbuhan dan perkembangan yang pesat. Pada usia ini anak paling peka dan potensial untuk mempelajari sesuatu, rasa ingin tahu anak sangat besar. Hal ini dapat kita lihat dari anak sering bertanya tentang apa yang mereka lihat. 
Apabila pertanyaan anak belum terjawab, maka mereka akan terus bertanya sampai anak mengetahui maksudnya. Di samping itu, setiap anak memiliki keunikan sendiri-sendiri yang berasal dari faktor genetik atau bisa juga dari faktor lingkungan. Faktor genetik misalnya dalam hal kecerdasan anak, sedangkan faktor lingkungan bisa dalam hal gaya belajar anak.

Anak usia dini suka berfantasi dan berimajinasi. Hal ini penting bagi pengembangan kreativitas dan bahasanya. Anak usia dini sukamembayangkan dan mengembangkan suatu hal melebihi kondisi yang nyata. Salah satu khayalan anak misalnya kardus, dapat dijadikan anak sebagai mobil-mobilan. Menurut Berg, rentang perhatian anak usia 5 tahun untuk dapat duduk tenang memperhatikan sesuatu adalah sekitar 10 menit, kecuali hal-hal yang biasa membuatnya senang. Anak sering merasa bosan dengan satu kegiatan saja. Bahkan anak mudah sekali mengalihkan perhatiannya pada kegiatan lain yang dianggapnya lebih menarik. Anak yang egosentris biasanya lebih banyak berpikir dan berbicara tentang diri sendiri dan tindakannya yang bertujuan untuk menguntungkan dirinya, misalnya anak masih suka berebut mainan dan menangis ketika keinginannya tidak dipenuhi. Anak sering bermain dengan teman-teman di lingkungan sekitarnya. Melalui bermain ini anak belajar bersosialisasi. Apabila anak belum dapat beradaptasi dengan teman lingkungannya, maka anak anak akan dijauhi oleh temantemannya. Dengan begitu anak akan belajar menyesuaikan diri dan anak akan mengerti bahwa dia membutuhkan orang lain di sekitarnya.

Karakteristik anak usia dini merupakan individu yang memiliki tingkat perkembangan yang relatif cepat merespon (menangkap) segala sesuatu dari berbagai aspek perkembangan yang ada. Sedangkan karakteristik anak usia dini menurut Richard D.Kellough (Kuntjojo, 2010) adalah sebagai berikut: a) egosentris, b) memiliki curiosity yang tinggi, c) makhluk sosial, d) the unique person, e) kaya dengan fantasi, f) daya konsentrasi yang pendek, g) masa belajar yang paling potensial. Egosentris adalah salah satu sifat seorang anak dalam melihat dan memahami sesuatu cenderung dari sudut pandang dan kepentingan diri sendiri. Anak mengira bahwa semuanya penuh dengan hal-hal yang menarik dan menakjubkan. Melalui interaksi dengan orang lain anak membangun konsep diri sehingga anak dikatakan sebagai makhluk sosial.

Anak memiliki daya imajinasi yang berkembang melebihi apa yang dilihatnya. Anak juga memiliki daya perhatian yang pendek kecuali terhadap hal-hal yang bersifat menyenangkan bagi anak. Berbagai perbedaan yang dimiliki anak penanganan yang berbeda mendorong pada setiap anak. Pada masa belajar yang potensial ini, anak mengalami masa peka untuk tumbuh dan berkembang dengan cepat. Anak usia dini merupakan masa peka dalam berbagai aspek perkembangan yaitu masa awal pengembangan kemampuan fisik motorik, bahasa, sosial emosional, serta kognitif. Menurut Piaget (Slamet Suyanto,2003: 56-72), anak memiliki 4 tingkat perkembangan kognitif yaitu tahapan sensori motorik (0-2 tahun), pra operasional konkrit (2-7 tahun), operasional konkrit (7-11 tahun), dan operasional formal (11 tahun ke atas).

Dalam tahap sensori motorik (0-2 tahun), anak mengembangkan kemampuannya untuk mengorganisasikan dan mengkoordinasikan dengan gerakan dan tindakan fisik. Anak lebih banyak menggunakan gerak reflek dan inderanya untuk berinteraksi dengan lingkungannya. Pada perkembangan pra operasional, proses berpikir anak mulai lebih jelas dan menyimpulkan sebuah benda atau kejadian walaupun itu semua berada di luar pandangan, pendengaran, atau jangkauan tangannya. Pada tahap operasional konkrit, anak sudah dapat memecahkan persoalan-persoalan sederhana yang bersifat konkrit dan dapat memahami suatu pernyataan, mengklasifikasikan serta mengurutkan. Pada tahap operasional formal, pikiran anak tidak lagi terbatas pada benda-benda dan kejadian di depan matanya. Pikiran anak terbebas dari kejadian langsung.

Dilihat dari perkembangan kognitif, anak usia dini berada pada tahap pra operasional. Anak mulai proses berpikir yang lebih jelas dan menyimpulkan sebuah benda atau kejadian walaupun itu semua berada di luar pandangan, pendengaran, atau jangkauan tangannya. Anak mampu mempertimbangkan tentang besar, jumlah, bentuk dan benda-benda melalui pengalaman konkrit. Kemampuan berfikir ini berada saat anak sedang bermain.

Pendidikan Anak Usia Dini merupakan salah satu bentuk penyelenggaraan pendidikan yang menitikberatkan pada peletakan dasar ke arah pertumbuhan dan perkembangan fisik (koordinasi motorik halus dan kasar), kecerdasan (daya pikir, daya cipta, kecerdasan emosi, kecerdasan spiritual), sosio emosional (sikap dan perilaku serta agama) bahasa dan komunikasi, sesuai dengan keunikan dan tahap-tahap perkembangan yang dilalui oleh anak usia dini. 
56 Vocabulary Mastery with Storytelling Methods and Conventionality Strategies and References to Students in The A1 TK Rahma Ciracas

\section{Penguasaan Kosakata}

Hakikat kosakata dasar (basic vocabulary) kata-kata yang tidak mudah berubah atau sedikit sekali memungkinkannya dipungut dari bahasa lain (Tarigan, 1993: 3). Kosakata (lexicom) adalah komponen bahasa yang memuat semua informasi tentang makna dan pemakaian kata. Gorys Keraf berpendapat bahwa kosakata adalah keseluruhan kata yang dimiliki oleh bahasa. (Keraf, 1984: 24).

Penguasaan seseorang terhadap sesuatu bahasa dapat dilakukan melalui berbagai sumber, baik melalui belajar langsung at, baik melalui belajar langsung atau tidak. Penguasaan bahasa dapat mempengaruhi seseorang dalam berpikir tentang apa yang dipikirkan dan menyimpanya dalam pikiran dan sewaktu-waktu dapat menggunakannya. (Bloom, 1954: 293) mengatakan bahwa penguasaan merupakan pengingatan suatu kegiatan yang diperoleh melalui proses belajar.

Dalam pengajaran bahasa, penguasaan kosakata merupakan penentu utama keberhasilan seseorang dalam berbahasa. Makin tinggi penguasaan kosakata dapat seseorang, makin besar kemungkinannya untuk terampil berbahasa. Nurgiyantoro mengatakan, "Penguasaan kosakata dapat dibedakan ke dalam penguasaan yang bersifat reseptif dan produktif, yakni kemampuan untuk memahami dan mempergunakan kosakata." (Nurgiyantoro: 2001).

Soedjito (1992) mengatakan bahwa kosakata (perbendaharaan kata) dapat diartikan sebagai berikut: (1) semua kata yang terdapat dalam satu bahasa, (2) kekayaan kata yang dimiliki seorang pembicara atau penulis, (3) kata yang dipakai dalam satu bidang ilmu pengetahuan, dan (4) daftar kata yang disusun seperti kamus disertai penjelasan secara singkat dan praktis (Soedjito, 1992: 1). Pendapat serupa seperti yang dikatakan oleh Adiwimarta (1998) bahwa kosakata adalah (1) semua kata yang terdapat dalam suatu bahasa, (2) kata-kata yang dikuasai oleh seseorang atau kata-kata yang dipakai oleh segolongan orang dari lingkungan yang sama, (3) kata-kata yang dipakai dalam suatu bidang ilmu pengetahuan, (4) dalam linguistik, seluruh morfem yang ada dalam satu bahasa, dan (5) daftar alfabetis disertai bahasa dan ketergantungannya (Adiwimarta, dkk.1998).

Untuk menambah perbendahaan kata, anak dapat diajak untuk membaca sedini mungkin. Riset menunjukkan bahwa anak-anak yang kaya dengan kosakata dan mempunyai pengalaman banyak dalam menggunakan bahasa akan lebih berhasil di sekolah daripada yang tidak mempunyai pengalaman sama sekali (Hart\&Risley, 1995).

Dalam buku Creative Curriculum for Preschool karangan Diane Trister Dodge (2002) disebutkan bahwa anak dapat menambah kosakata dengan berbagai cara antara lain:

1. Dengan melibatkan anak pada pembicaraan yang bersifat informal, bercakap-cakap beik dengan teman maupun orangtua.

2. Dengan mengajak bernyanyi, membaca puisi, bermain dengan jari jemri atau gerakan fisik. 3 . Dengan memberikan pengalaman pertama dalam menperdengarkan kata-kata baru khususnya dalam menggambarkan apa yang sedang mereka lakukan.

3. Membaca degan jelas mendengarkan cerita dari buku dan membahas kata-kata baru dalam cerita tersebut.

4. Dengan melihat gambar, anak dapar mengeksplorasi serta ada dialog antara orangtua dan anak. Misanya: Putri Salju sedang apa, Nak?. Pada awalnya, batita masih terbatas kosakatanya. Tetapi, mereka tetap bisa paham jika kita menggunakan kalimat yang sederhana dan pendek.

Berdasarkan pendapat tersebut dapat disimpulkan bahwa kosakata adalah perbendaharaan kata yang dimiliki seseorang dan dapat dipergunakan dalam komunikasi lisan maupun tulisan.

4. Perkembangan Bahasa Anak Usia Dini

Perkembangan bahasa anak meliputi perkembangan fonologis (mengenal dan memproduksi suara), perkembangan kosakata, perkembangan semantik, perkembangan sintaksis, dan perkembangan pragmatik atau penggunaan bahasa untuk keperluan komunikasi. Perkembangan bahasa anak usia dini dipengaruhi oleh kematangan sel korteks, dukungan lingkunga, dan keterdidikan lingkungan. Anak akan belajar meniru dan mencoba mengekspresikan keinginan dan perasaannya.

Pemerolehan dan perkembangan bahasa anak usia dini dapat diperoleh melalui pengasuhan yang memberikan stimulasi sensorimotorik, sering berdiskusi dengan anak serta memberikan dorongan untuk mengungkapkan dirinya (Lazuardi via Musfiroh, 2008: 8). Menurut Piaget, perkembangan bahasa anak TK masih bersifat egosentrik dan self-expressive. Pada masa ini, anak menguasai 
kemampuan bicara, tetapi mereka masih harus banyak belajar. Kosakata yang diperoleh anak pada awal masuk TK, kira-kira berjumlah 2000 kata.

Nurgiyantoro (2005: 62) mengatakan bahwa pada masa ini (3-5 tahun), anak berada dalam tahap pra-operasional (Piaget); pengalaman pada tahap prakarsa versus kesalahan (Erickson); penafsiran baik dan buruk, boleh dan tidak boleh, berdasarkan konsekuensi fisik dan hadiah atau hukuman; perkembangan bahasa berlangsung amat cepat, dan pada usia lima tahun sudah mampu berbicara kalimat kompleks; dapat membedakan warna dan mengenali atribut yang berbeda pada objek yang mirip; cara berpikir dan berperilaku egosentris; belajar lewat pengalaman tangan pertama; mulai menyatakan sesuatu secara bebas dan belajar melalui permainan imajinatif; membutuhkan pujian dan persetujuan dari orang dewasa; kurang memperhatikan masalah waktu; dan mengembangkan rasa tertarik dalam aktivitas kelompok.

Menurut Elizabeth B. Hurlock (1978: 114) keterampilan berbicara anak harus didukung dengan perbendaharaan kata atau kosakata yang sesuai tingkat perkembangan bahasa. Meskipun sarana yang lain ada tapi kosakata anak minim akan menyebabkan anak tidak dapat berbicara. Belajar berbicara merupakan proses bagi anak maupun orang dewasa. Proses berlangsung sesuai kebutuhan anak sehingga anak juga akan mampu berbicara sesuai dengan kemampuan atau kebutuhan. Belajar berbicara anak pada usia dini dapat digunakan sebagai sosialisasi dalam berteman dan melatih kemandirian anak. Semakin sering anak berhubungan dengan orang lain maka semakin besar dorongan untuk berbicara.

5. Cara Anak Menguasai Makna Kata

Menurut Dardjowidjojo (2010: 262), anak tidak menguasai makna kata secara sembarangan. Ada strategi-strategi tertentu yang diikuti (Golinkoff dkk 1994 dalam Gleason dan Ratner 1998: 361). Anak memakai, misalnya, strategi referensi dengan menganggap bahwa kata pastilah menrujuk pada benda, perbuatan, proses, atau atribut. Dengan strategi ini anak yang baru mendengar suatu kata baru akan menempelkan makna kata itu pada salah satu dari referensi di atas. Bila kata itu cabe, dia akan melekatkan makna kata itu pada benda yang dirujuk dengan nama itu. Bila kata baru itu adalah ngumpet, dia akan memaknakan kata itu dengan perbuatan penyembunyian diri, dst.

Strategi lain adalah strategi cakupan objek (object scope). Pada strategi ini kata yang merujuk pada suatu objek merujuk pada objek itu secara keseluruhan, tidak hanya sebagian dari objek itu saja. Jadi, kalau anak diperkenalkan kepada objek seperti sepeda maka keseluruhan dari sepeda itu yang akhirnya dikuasainya, bukan hanya ban atau sadelnya saja. Pada awal pemerolehan bisa terjadi bahwa anak hanya mengambil salah satu fiturnya saja, tetapi akhirnya terbentuk pengertian bahwa yang dinamakan sepeda adalah keseluruhan dari objek itu.

Strategi ketiga adalah strategi peluasan (extendability). Strategi ini mengasumsikan bahwa kata tidak hanya merujuk pada objek aslinya saja tetapi juga pada objek-objek lain dalam kelompok yang sama itu. Kalau, misalnya, anak diperkenalkan dengan objek yang bernama kucing, yang kebetulan bulunya hitam, dia akan tahu bahwa kucing lain yang bulunya putih juga dinamakan kucing.

Strategi keempat adalah cakupan kategorial (categorial scope). Strategi ini menyatakan bahwa kata dapat diperluas pemakaiannya untuk objek-objek yang termasuk dalam kategori dasar yang sama. Setelah diperkenalkan dengan perkutut sebagai burung, dan kemudian dia melihat beo maka dia akan tahu bahwa beo juga termasuk dalam kategori dasar yang sama dengan perkutut, yakni, burung. Dia akan merujuk beo sebagai burung pula.

Strategi kelima adalah strategi "nama-baru - kategori takbernama" (novel name-nameless category). Anak yang mendengar kata, dan setelah dicari dalam leksikon mental dia ternyata kata ini tidak ada rujukannya, maka kata ini akan dianggap kata baru dan maknanya ditempelkan pada objek, perbuatan, atau atribut yang dirujuk oleh kata itu. Jadi, waktu anak mendengar, misalnya kata kancing dia akan mencari dalam leksikon mental dia apa rujukan dari kata itu. Setelah ternyata rujukan itu belum ada, maka anak akan menganggap kata itu kata baru dan menempelkan maknanya pada benda kancing itu. Strategi inilah yang membuat anak cepat sekali dalam menambah kosa katanya sejak umur 1;8.

Strategi keenam adalah strategi konvensionalitas (convensionality). Anak berasumsi bahwa pembicara memakai kata-kata yang tidak terlalu umum tetapi juga tidak terlalu khusus. Kemungkinannya adalah sangat kecil untuk orang dewasa memperkenalkan kata binatang atau makhluk untuk merujuk seekor perkutut. Juga kecil kemungkinannya untuk dia memakai kata perkutut Bangkok. Yang umum terjadi adalah bahwa dia akan memakai kata burung pada anak untuk merujuk 
58 Vocabulary Mastery with Storytelling Methods and Conventionality Strategies and References to Students in The A1 TK Rahma Ciracas

pada perkutut itu. Strategi-strategi yang sifatnya universal ini membantu anak dalam menguasai makna kata.

6. Manfaat Bercerita bagi Anak

Sastra menurut Lukens (2003: 9) menawarkan kesenangan dan pemahaman. Kehadiran sastra pertama kali adalah memberikan hiburan yang menyenangkan. Sastra menampilkan cerita yang menarik dan mengajak pembaca untuk memanjakan fantasi. Selain itu, sastra juga memberikan pemahaman yang lebih baik tentang kehidupan bagi anak-anak. Melalui sastra, anak-anak dapat belajar mengeksplorasi diri tentang kehidupan lewat bacaan yang memberikan stimulus imajinasi anak. Isi kandungan pemahaman tentang eksplorasi kehidupan tersebut diungkapkan dalam bahasa yang menarik.

Sastra dan anak menjadi dua hal yang sangat berhubungan. Sastra dapat membantu anak memperoleh segala sesuatu yang berhubungan dengan perkembangan diri anak, misalnya perkembangan emosional, imajinasi, rasa sosial, rasa etis dan religius, perkembangan bahasa, pengembangan nilai keindahan, penanaman wawasan multikultural, dan penanaman kebiasaan membaca (lebih lanjut lihat Nurgiyantoro, 2005:35-47). Sebaliknya, keberadaan dunia anak semakin memperkaya perkembangan sastra, khususnya sastra untuk anak-anak.

Menurut Prof. Dr. Dedi Supriadi (2003:44), bercerita adalah menuturkan sesuatu yang mengisahkan tentang perbuatan, pengalaman atau suatu kejadian yang sungguh-sungguh terjadi maupun rekaan belaka. Metode bercerita merupakan salah satu pemberian pengalaman belajar bagi anak TK dengan membawakan cerita kepada anak secara lisan. Cerita yang dibawakan guru harus menarik dan mengundang perhatian anak dan tidak lepas dari tujuan pendidikan anak TK. Efek fun dan learning yang terkandung dalam sebuah cerita atau dongeng merupakan energi gambaran kekuatan sebuah cerita. Di samping itu, cara bercerita kita sebagai orang tua tentu lebih mengentalkan efek tersebut agar lebih disukai anak-anak (Moeslihatoen, 2004: 157).

Dalam penelitian ini digunakan metode bercerita dengan media boneka Boneka yang dapat dipergunakan dalam bercerita berbentuk boneka dengan wujud aneka satwa. Hal ini dipilih penulis karena sesuai dengan topik pengajaran di TK tentang pengenalan satwa. Penceritaannya pun ada kaitannya dengan kebiasaan satwa.Misalnya, burung dapat terbang, kelinci melompat dan menyukai wortel atau ciri-ciri binatang seperti gajah mempunyai gading, kerbau mempunyai tanduk.

\section{Metode}

Pengumpulan data dalam penelitian ini diperoleh dengan observasi, rekaman kegiatan serta tanya jawab dengan guru dan peserta didik. Untuk mengetahui kosakata yang telah dikuasai oleh anak, guru bersama peneliti mengadakan pretest dengan menggunakan metode bermain dan penugasan. Hasilnya dicatat dalam tabel observasi 1 . Kemudian, guru menerapkan metode bercerita dengan strategi konvensionalitas dan referensi. Hasilnya juga dicatat dalam tabel observasi 2.

\section{Hasil dan Diskusi}

Karena penelitian ini berbentuk mini riset, maka hanya digunakan 2 siklus saja yaitu sebelum menggunakan teknik bercerita dan sesudah menggunakan teknik bercerita. Pokok bahasan yang akan diajarkan saat penelitian berlangsung sesuai dengan silabus yaitu tentang pengenalan satwa.

1. Sebelum menggunakan teknik bercerita

Sebelum menggunakan metode bercerita, guru menggunakan metode campuran yaitu bermain, menggunakan gambar, dan penugasan. Sebagai contoh:

Guru : "Ayoo, anak-anak siapa yang dapat menemukan binatang yang ada di kebunnya Ali"(sambil menunjuk buku bergambar tokoh Ali dengan binatang peliharaannya).

Peserta didik $\quad$ :(sambil berlarian mencari letak mainan berbentuk satwa dari karet) "Ini bu... saya nemu kodok."

"Saya nemu ular."

"yeee...kelinci." 
Dalam proses ini, guru hanya sampai pada pujian saja tidak menggali lebih mendalam dengan pertanyaan-pertanyaan seputar binatang tersebut. Hal ini pun terlihat dari contoh berikut ini:

Guru : "Adit, coba kamu ceritakan binatang apa yang kamu temukan itu?"

Adit : (Diam saja sambil tersenyum)"...ini kucing bu. Aku juga punya kucing di rumah, tapi namanya manis."

Guru : "Iya, itu kucing, siapa yang di rumah punya kucing?"

Peserta didik : "Sayaaa..."

Guru : "Kalo suara kucing gimana coba?"

Peserta didik : " "ngeoong. . .ngeong (semua serentak)

Guru : "Di kebun Ali banyak binatangnya ya, coba binatang apa aja yang ada di kebunnya Ali?"

Peserta didik : "Kucing, anjing, klinci, bulung, ayaammm. ."

Guru : "Terus apalagi hayo?"

Daffa : "Bu guru, aku juga punya klinci, tapi udah mati sekalang.'

Guru : "Iyaa Daffa," ayooo itu yang ada di kolam (sambil menunjuk ke gambar) binatang apa coba?"

Riski : "Bebek."

Reza : "itu kan bulung."

Kosakata yang telah dikuasai anak pada tahap observasi pertama ini dicatat dalam tabel observasi 1 berikut ini.

Tabel 1. Observasi

\begin{tabular}{|c|c|c|c|}
\hline No. & Nama Siswa & $\begin{array}{c}\text { Kosakata Binatang yang Telah Dikuasai Anak } \\
\text { Tahap } 1 \\
\end{array}$ & $\begin{array}{c}\begin{array}{c}\text { Kosakata yang Berhubungan } \\
\text { dengan Binatang }\end{array} \\
\end{array}$ \\
\hline 1 & Ardina Rahma & cicak, kucing, ayam, kelinci & ngeong, kukuluyuk \\
\hline 2 & Aufa Zahra & ayam, kucing, gukguk, kelinci & gukguk, kukuluyuk \\
\hline 3 & Asrorul A & bulung (burung), bebek, kucing, kelinci & ngeong, sayap \\
\hline 4 & M. Ibnu A & kakaktua, ayam, kucing, angsa & kukuluyuk \\
\hline 5 & Fahmi Ahmad & cicak, ayam, kelinci, sapi, bebek & kukuluyuk \\
\hline 6 & Aditya Raka & kodok, bulung (burung), kakaktua & Sayap \\
\hline 7 & M. Juanda R & sapi, bulung, anjing, kucing & meong, gukguk \\
\hline 8 & M. Alviano R & bulung, bebek, kucing, ayam, gukguk & kukuluyuk, wekwek \\
\hline 9 & Hikmah Reza S & sapi, bulung, kakaktua, kucing & meong, sayap \\
\hline 10 & Azzahra Sekar & bulung, kucing, kelinci & meong \\
\hline 11 & Salma Tyas F & ayam, bulung, kucing, kelinci & kukuluyuk, meong \\
\hline 12 & Riski Oktaviani & kelinci, kucing, anjing, ulal, bulung & meong, gukguk \\
\hline 13 & Syania Fauziah & bulung, ayam, kucing, kelinci, sapi & kukuluyuk, meong \\
\hline 14 & Ghaitsa Kahla & sapi, ayam, bulung, kelinci, kucing & meong \\
\hline
\end{tabular}

Dari data yang didapat penulis, guru kurang mempunyai kreativitas dalam menjelaskan gambar, bertanya jawab dengan peserta didik. Seharusnya guru dapat menggali lagi dengan pertanyaan misalnya, "jalannya kelinci gimana, coba siapa yang bisa menirukan? Iya. . jalannya melompat."

Dalam tahap pertama, guru juga tidak membetulkan jawaban peserta didik, misalnya:

Guru : "Itu yang didekat kakinya Ali, binatang apa?"

Fahmi : "itu kan cicak ya bu gulu."

Riski : "Butaaannn! Itu ulal. .!"

Daffa : :Cicak, tauuu!" Cicak besal!"

Dara : "Iya kayak Kodomo ya"

Guru : (Sambil mempersiapkan gambar berikutnya)” yaaa sudah, sekarang, liat gambar ya, itu si Ali kasih makan binatang kesayangannya, apa saja ya?"

Peserta didik : "ayam. . klinci! bulung! Kucing. . gukguk"

Alviano : "Ada gukguk ya. . aku punya dong boneka gukguk."

Pada saat anak menyebut nama binatang yang dimaksud itu salah, guru tidak berusaha membetulkan nama binatang dengan benar, misalnya ketika Daffa dan teman lainnya menyebut "cicak" untuk binatang kadal yang ada di kebun Ali (dalam gambar), atau saat Dara yang mengatakan bahwa kadal 
60 Vocabulary Mastery with Storytelling Methods and Conventionality Strategies and References to Students in The A1 TK Rahma Ciracas

menyerupai kodomo (bukan Komodo). Cara penentuan makna yang kurang tepat ini biasa terjadi pada anak usia dini.

Penyebutan kata "gukguk" untuk kata "anjing" seperti yang dilakukan oleh Alviano dan Dara yang menganggap kadal seperti kodomo (gambar komodo yang ada di pasta giginya yang merknya "Kodomo", ini menunjukkan bahwa dalam memahami atau menentukan makna suatu kata, anak mengikuti prinsip universal yaitu penggelembungan makna dan penciutan makna. Pada penggelembungan makna, saat anak diperkenalkan dengan suatu konsep baru, anak cenderung untuk mengambil salah satu fitur dari konsep itu, lalu menerapkannya pada konsep lain yang memiliki fitur tersebut (Dardjowidjojo, 2010: 260). Contohnya, saat anak diperkenalkan pertama kali dengan konsep "gukguk" maka ketika ia melihat semua binatang yang menyerupai anjing, apakah itu serigala, anjing herder, mainan anjing, gambar, si anak akan menamainya dengan "gukguk". Demikian juga dengan kata"cicak" yang dilontarkan oleh Daffa dan Fahmi, mereka telah diperkenalkan bentuk binatang cicak pertama kali, sehingga ketika mereka melihat bentuk binatang seperti cicak yaitu kadal, mereka langsung menyebutnya dengan "cicak".

Ketika Daffa menyebut binatang cicak sebagai cicak besar dan Dara menyamakan dengan "kodomo", hal ini sebetulnya Dara mengikuti prinsip penciutan makna. Dara telah diperkenalkan dengan konsep kodomo yang dilihatnya pada iklan di televisi dan pada pasta giginya yang bermerk Kodomo serta bergambar seperti cicak besar. Dara menyebut gambar kadal seperti kodomo. Jadi menurut Dara, cicak besar itu namanya "kodomo".

1. Penggunaan Teknik Bercerita

Pada teknik bercerita ini guru menggunakan strategi konvensionalitas dan referensi. Guru akan menggunakan kata-kata yang sudah umum digunakan, yang telah didapat anak dari lingkungannya. Selain itu, guru juga menggunakan strategi referensi yang merujuk pada benda, perbuatan, proses, atau atribut. Bahan yang dibutuhkan pada tahap ini adalah boneka binatang yang menyerupai wujud aslinya, temanya masih tetap sama dengan kegiatan pada tahap I yaitu tentang binatang di sekitar rumah Ali Berikut kegiatan pengenalan kosakata binatang dengan teknik bercerita. Setelah memberi salam kepada guru, peserta didik kelas A1 TK Rahma duduk dengan tenang.

Guru : "Anak-anak, pagi ini Ibu akan bercerita, siapa yang mau mendengarkan?"

Peserta didik : : "Saya, Bu Gulu!" (menjawab serentak).

Guru : "Kalo begitu kita duduk di bawah aja ya pake tiker." (sambil menyuruh asistennya untuk merapikan kursi dan menggelar tikar)

Kemudian Guru mengeluarkan boneka-boneka binatang dari dalam tasnya (boneka binatang ini merupakan wujud bantuan Lembaga Penelitian tempat peneliti mengabdi)

Peserta didik : : (dengan terkagum-kagum dan berusaha mendekat) "iiiih ada kodok." "Iya, Bu Guru ada ulal gak? Aku takut ulal."

Bu Guru : : "Ular gak ada di kebunnya Ali. Kebunnya Ali selalu bersih karena Ali sama ayahnya selalu membersihkan kebunnya. Jadinya, ularnya pergi jauh ke hutan. Nah, kalian juga harus selalu jaga kebersihan ya, kalo buang sampah harus di tempat sampah, jangan sembarangan."

Setelah semua siap, Ibu Guru mulai bercerita tentang Ali dan binatang di sekitar rumah dan kebunnya. Di sela-sela cerita, guru aktif melakukan dialog atau tanya jawab dengan peserta didik seperti contoh berikut ini.

Guru

: "Si Ali sangat sayang sama semua binatang yang ada di rumah dan kebunnya. Semua selalu diberi makan, (sambil memegang sebuah boneka berwujud anak laki- laki) naaah ini Ali sedang memberi makan kelincinya. Dia memberi kelincinya ini (sambil memegang wortel), apa namanya hayooo?"

Peserta didik $\quad:$ (diam)

Guru : "Namanya wortel. Apa namanya?"

Peserta didik : "Wollteel." (serentak)

Guru : : "Kelincinya mendekati Ali, pengin banget makan wortelnya. Gimana jalannya kelinci?" 
Syania

Guru

: "Melompat lompat"

: "Iya melom..pat. coba bisa gak niruin kelinci melompat?" (sambil memeragakan boneka kelinci yang dipegang melompat-lompat). Semua peserta didik melompat-lompat seperti kelinci.

Dari ilustrasi kegiatan tersebut, guru menggunakan strategi referensi yaitu dengan langsung merujuk pada bendanya (wortel) dan perbuatan/tindakan (melompat). Pada saat ditanya tentang benda yang ditunjuk oleh guru, peserta didik diam saja dan setelah Guru memberitahu nama benda tersebut dengan kata baru yaitu "wortel", si anak akan mencari dalam leksikon mentalnya apa rujukan dari kata itu. Menurut Dardjowidjojo (2010: 263), setelah mencari dalam leksikon mentalnya dan ternyata belum ada, maka anak akan menganggap kata itu kata baru dan menempelkan makna itu pada benda yang baru saja didengar, seperti "wortel". Strategi ini dilakukan dan divariasi dengan strategi konvensionalitas yaitu menggunakan kata-kata yang sudah umum. Misalnya seperti contoh berikut. Guru : "Ali juga memberi makan burung kesayangannya. Naah, ini ada burung di atas pohon, melihat Ali membawa roti dia langsung turun. . Ternyata dia suka roti ya. Nah ini, burungnya turun pake apa turunnya? "

Kahla : "Ntal bulungnya jatuh."

Ibnu : "Dia kan terbang” (Ibnu, anak yang umurnya hampir 5 tahun)

Guru : "Iya. Burungnya turunnya pake sa..yap. Dia terbang pake sayap, nih" (sambal mengembangkan sayapnya boneka burung yang dipegangnya dan diperagakan terbang mendekati tokoh Ali. Burungnya gmn turunnya?"

Peserta didik : "pake sayap." "telbang. . pake sayap"

Guru : "Iya terbang pake sayap." Nah ini sayapnya."

Reza : "Boleh pegang gak, sayapnya?"

Guru : "Boleeeh."

Salma : "Aku juga mau pegang.” Ini kan kakaktua ya bu?"

Reza : "Ini bulung. . aku mau pegang lagi dong!"

Peserta didik yang lain juga minta agar diperbolehkan pegang sayap boneka burung tersebut.

Guru

: "Iya Salma ini burung Kakaktua namanya. Dia juga burung ya, punya sayap, terus dia punya apa ini. untuk makan?” (sambil menunjuk paruh burung).

Peserta didik : (diam)

Dafa : "mulutnya bulung itu."

Guru

Peserta didik : "Iya, mulutnya burung namanya paruh." Apa namanya?"

Dari ilustrasi kegiatan di atas, Guru aktif merujuk benda atau tindakan, misalnya "sayap", "paruh", "terbang". Ada beberapa kesalahan kosakata yang diterima pada tahap I, yaitu kata "sapi" yang merujuk pada binatang kerbau, kata "bebek" yang merujuk pada binatang angsa, dan kata "cicak" serta "ular" yang merujuk pada binatang kadal. Seperti telah dijelaskan sebelumnya bahwa cara anak dalam menentukan makna suatu kata anak menggunakan cara penggelembungan dan penyempitan makna. Dalam kasus kesalahan tersebut, anak menggunakan cara penggelembungan makna karena anak-anak tersebut telah diperkenalkan oleh lingkungannya dengan konsep 'sapi', 'bebek', 'cicak', dan 'ular'. Dalam hal ini, penggelembungan makna yang terjadi itu berdasarkan bentuk atau wujudnya. Setelah kegiatan bercerita disertai tanya jawab dengan peserta didik selesai, kegiatan selanjutnya adalah tanya jawab bebas seperti contoh berikut ini.

Guru : "Banyakya binatang yang ada di kebun dan di rumah Ali." Apa saja ya?" Sambil merapikan beberapa binatang agar dekat dengan boneka Ali)

Peserta didik : :"kucing, anjing, bulung.."

$$
\text { "klinci. . }
$$

Guru

Daffa

: "Yang seperti Sapi ini namanya apa, tadi?"

Rahma

: "kelbau bu. . ada tanduknya"

Guru

: “Ada kodok. sama kadal.” Semua peserta didik saling bersahut-sahutan.

: "Iya pinter semuanya ya. Nah, tadi Ali bawa makanan ya, buat burungnya, 
62 Vocabulary Mastery with Storytelling Methods and Conventionality Strategies and References to Students in The A1 TK Rahma Ciracas

Salma : "Lotii, bu. . maemnya pake paluh (sambil menirukan tangannya dijadikan paruh didekat mulutnya).

Dalam kegiaatan ini guru bercerita sambil menggunakan strategi umum atau konvensionalitas serta referensi. Seperti contoh berikut.

Riski

: "Bu gulu. . kadalnya juga mau makan (sambil mengambil boneka kadal)...iiih lidahnya panjang."

Guru

: "Iya boleh, makan ya, nii makanannya." Kalo kadal makannya pake liii...daah. Liat ya lidahnya panjang, lidahnya keluar.. menjulur keluar.. (guru menjulurkan) gimana lidah kadal? menju..luur."

Peserta didik : : "menjuluur." (sambil mengeluarkan lidahnya).

Hasil dari penguasaan kosakata pada anak melalui metode bercerita dengan strategi referensi dan konvensionalitas tertuang dalam tabel berikut ini:

Tabel 2. Observasi

\begin{tabular}{|c|c|c|c|}
\hline No. & Nama Siswa & $\begin{array}{c}\text { Kosakata Binatang yang Telah Dikuasai Anak } \\
\text { Tahap } 1\end{array}$ & $\begin{array}{c}\text { Kosakata yang Berhubungan dengan } \\
\text { Binatang }\end{array}$ \\
\hline $\begin{array}{l}1 \\
2\end{array}$ & Ardina Rahma & $\begin{array}{l}\text { kadal, kucing, ayam, kelinci, angsa, kerbau, aning } \\
\text { ayam, kucing, anjing, kelinci, burung, angsa, }\end{array}$ & melompat, tanduk, wortel, berkokok \\
\hline 3 & Aufa Zahra & $\begin{array}{l}\text { kerbau } \\
\text { burung, kucing, kelinci, ayam, kerbau, angsa, }\end{array}$ & meong, melompat, terbang, sayap \\
\hline & Asrorul A & kadal & sayap, terbang, wortel, tanduk, paruh \\
\hline $\begin{array}{l}4 \\
5\end{array}$ & M. Ibnu A & $\begin{array}{l}\text { burung kakaktua, ayam, kucing, angsa, anjing } \\
\text { kadal, ayam, kelinci, kerbau, angsa, anjing, }\end{array}$ & sayap, terbang, wortel, gonggong \\
\hline & Fahmi Ahmad & burung & melompat, tanduk, sayap, terbang \\
\hline $\begin{array}{l}6 \\
7\end{array}$ & Aditya Raka & $\begin{array}{l}\text { kodok, burung, kadal, ayam, angsa, kucing, kelinci } \\
\text { angsa, burung, anjing, kucing, kerbau, ayam, }\end{array}$ & melompat, terbang, berenang, sayap \\
\hline 8 & M. Juanda R & $\begin{array}{l}\text { kadal } \\
\text { burung, angsa, kucing, ayam, kerbau, kelinci, }\end{array}$ & sayap, terbang, tanduk, gonggong \\
\hline & M. Alviano R & kodok & melompat, wortel, sayap, terbang \\
\hline 9 & Hikmah Reza S & ayam, burung kakaktua, kucing, kelinci, kodok & sayap, terbang, melompat, berkokok \\
\hline 10 & Azzahra Sekar & burung, kucing, kelinci, kadal, kerbau & melompat, tanduk, menjulur, paruh \\
\hline $\begin{array}{l}11 \\
12\end{array}$ & Salma Tyas F & $\begin{array}{l}\text { ayam, burung, kucing, kelinci, anjing, angsa } \\
\text { kelinci, kucing, anjing, kadal, burung, angsa, }\end{array}$ & sayap, terbang, melompat, berkokok \\
\hline $\begin{array}{l}13 \\
14\end{array}$ & $\begin{array}{l}\text { Riski Oktaviani } \\
\text { Syania Fauziah }\end{array}$ & $\begin{array}{l}\text { kerbau } \\
\text { burung, ayam, kucing, kelinci, kadal, angsa, kodok } \\
\text { kerbau, ayam, burung, kelinci, kucing, anjing, }\end{array}$ & $\begin{array}{l}\text { melompat, wortel, sayap, menjulur } \\
\text { melompat, berenang, sayap, terbang }\end{array}$ \\
\hline & Ghaitsa Kahla & angsa & tanduk, melompat, gonggong, paruh \\
\hline 15 & Syifa Marwah & burung, ayam, kucing, kelinci, angsa, kerbau & sayap, terbang, melompat, wortel \\
\hline 16 & Daranora M & burung, kerbau, ayam, kucing, kelinci, anjing & tanduk, melompat, gonggong, sayap \\
\hline 17 & Daffa A & kucing, kelinci, ayam, burung, angsa, kerbau & melompat, kerbau, sayap, terbang \\
\hline $\begin{array}{l}18 \\
19\end{array}$ & Fahri Maulana & $\begin{array}{l}\text { kodok, kadal, ayam, burung, kerbau, angsa } \\
\text { anjing, kucing, kerbau, burung, kelinci, kadal, }\end{array}$ & melompat, menjulur, tanduk, sayap \\
\hline 20 & $\begin{array}{l}\text { Marsya Rasya } \\
\text { Nawa Sofia }\end{array}$ & $\begin{array}{l}\text { angsa } \\
\text { kelinci, burung, ayam, kucing, anjing, kadal }\end{array}$ & $\begin{array}{l}\text { gonggong, tanduk, melompat, paruh } \\
\text { melompat, sayap, gonggong, menjulur }\end{array}$ \\
\hline
\end{tabular}

\section{Simpulan}

Dari penelitian yang telah dilakukan, dapat disimpulkan bahwa:

1. Pemanfaatan metode bercerita kepada anak efektif meningkatkan pemerolehan kosakata anak.

2. Pemanfaatan metode bercerita dengan strategi konvensionalitas dan referensi sangat efektif dalam penguasaan kosakata anak

3. Pemanfaatan metode bercerita dengan tanya jawab serta dialog yang intensif dapat meningkatkan penguasaan kosakata pada anak. 


\section{Ucapan Terima Kasih}

Ucapan terima kasih kepada Kepala PAUD/TK Rahma Ciracas, yang telah mengizinkan penulis melakukan observasi dan pengambilan data di PAUD/TK Rahma Ciracas.

\section{Daftar Rujukan}

Aisyah, Siti dkk. Perkembangan dan Konsep Dasar Pengembangan Anak Usia Dini. Jakarta: Universitas Terbuka. 2007.

Dardjowidjojo. Psikolinguistik: Pengantar Pemahaman Bahasa Manusia. Jakarta: Yayasan Obor Indonesia. 2010.

Dodge, Trister Diane. The Creative Curriculum for Preschool, 4th edition. Teaching Stategies Inc. 2002.

Lukens, Rebecca J. A Critical Handbook of Children,s Literature. New York: Longman. 1999.

Majid, Abdul Aziz Abdul. Mendidik dengan Cerita. Bandung: PT Remaja Rosdakarya. 2002

Mansur. Pendidikan Anak Usia Dini dalam Islam. Yogyakarta: Pustaka Pelajar, 2005.

Moeslichatoen. Metode Pengajaran Di Taman Kanak-Kanak. Jakarta: PT Rineka Cipta. 2004.

Musfiroh, Tadkiroatun. Bercerita Untuk Anak Usia dini. Jakarta: Depdiknas. 2005.

Musfiroh, Tadkiroatun. Memilih, Menyusun, dan Menyajikan Cerita untuk Anak Usia Dini. Yogyakarta: Tiara Wacana. 2008.

Nurgiyantoro, Burhan. Sastra Anak: Pengantar Pemahaman Dunia Anak. Yogyakarta: Gadjah Mada University Press. 2005.

Santosa, Sugeng. Pendidikan Anak Usia Dini. Jakarta: Yayasan Citra Pendidikan. 2002

Soenardi, Sabrur R. (ed). Teknik Menulis Cerita Anak. Yogyakarta: Pinkbooks. 2003.

Sugihastuti. Serba-Serbi Cerita Anak. Yogyakarta: Pustaka Pelajar. 1996.

Suyanto, Slamet. Dasar- dasar Pendidikan Anak Usia Dini (Yogyakarta: Hikayat Publishing. 2005

Tarigan, Henry Guntur. Pengajaran Kosakata. Bandung: Angkasa. 1993.

Undang- Undang Republik Indonesia No. 20 Tahun 2003 Tentang Sistem Pendidikan Nasional 